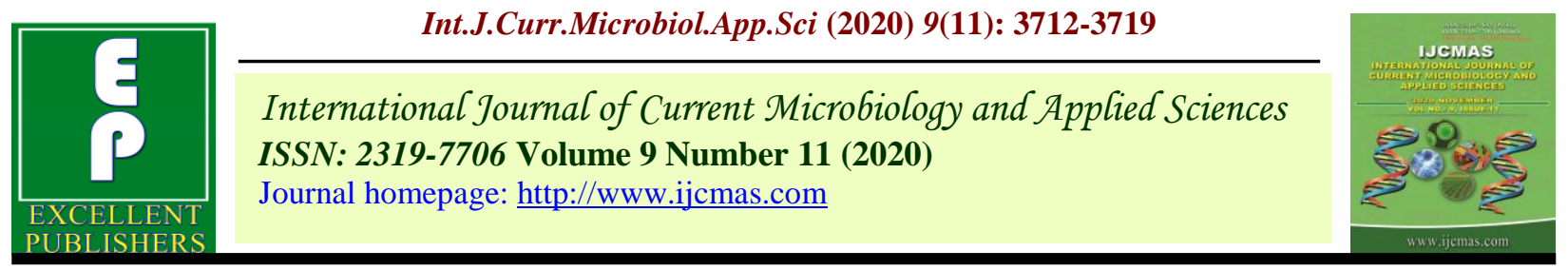

Original Research Article

https://doi.org/10.20546/ijcmas.2020.911.445

\title{
Effect of Integrated Nutrient Management on Growth, Yield and Economics of Cumin (Cuminum cyminum L.)
}

\author{
S. S. Desai", M. G. Chaudhary, R. S. Patel and J. R. Joshi \\ Department of Agronomy, C. P. College of Agriculture, Sardarkrushinagar Dantiwada \\ Agricultural University, Sardarkrushinagar, Gujarat, India \\ *Corresponding author
}

A B S T R A C T

\begin{tabular}{|l|}
\hline Ke y w o r d s \\
Cumin, \\
Vermicompost, \\
Azotobacter, PSB \\
\hline Article Info \\
\hline $\begin{array}{l}\text { Accepted: } \\
\text { 24 October } 2020 \\
\text { Available Online: } \\
10 \text { November } 2020\end{array}$ \\
\hline
\end{tabular}

\begin{abstract}
A field experiment was carried out at Agronomy Instructional Farm, C. P. College of Agriculture, Sardarkrushinagar Dantiwada Agricultural University, Sardarkrushinagar during rabi season of 2017-18 to study the effect of integrated nutrient management on growth, yield and economics of cumin. The experiment consisting ten treatments was laid out in randomised block design with four replications on loamy sand soil. Significantly higher plant height at harvest, number of branches per plant, number of umbels per plant, number of umbellates per umbel, number of seeds per umbellate, seed yield and straw yield were recorded with the treatment $\mathrm{T}_{9}(50 \% \mathrm{RDN}$ through vermicompost $+50 \%$ $\mathrm{RDN}$ through fertilizer + Azotobacter $+\mathrm{PSB})$. It also recorded highest gross and net income as compared to rest of the treatments.
\end{abstract}

\section{Introduction}

Seed spices are known as an integral part of Indian culture that's why India is known as home of spices. Among all the major seed spices, cumin (Cuminum cyminum L.) locally known as "Jeeru" is one of the important spice crop. Cumin is enriched in essential flavouring ingredient among all the spices. The seeds or powdered are used in soaps, sausages, beverages, pickles, cheese, bread and seasoning cakes etc. Cumin aldehyde or cuminol is 36.31 per cent in cumin which attributes the specific value added aroma. It has carminative, stomatic, anti-diarrheal and dyspecial medicinal properties. Cumin occupies 47.0 per cent of total seed spices area but accounts for 35.7 per cent of total seed spices production in the country. Adequate mineral fertilization is considered to be one of the most important pre-requisites with respect to plant nutrients for better growth and development of a plant. The gap between the nutrient removal and supply cannot be bridge up by the application of any single nutrient but this has to be achieved with balanced use of fertilizers. Indian farmers pay reasonable attention to cultivation, especially in respect of seedbed preparation, manuring and irrigation, however sufficient attention has not been paid to nutrient management aspect which remains 
one of the constraints in boosting up the production. Organic manure and bio-fertilizer play important role in crop production. It acts on the soil physical properties, organic matter promotes formation of soil crumb, thus makes the soil friable and thereby, facilitates the proper movement of air and water as well as absorption of rain water. It also adds plant nutrients to the soil and organic acid during dry matter decomposition which act on the insoluble nutrients reserve in the soil and make them available. Inoculation of seed with Rhizobium recorded higher protein content due to more nitrogen fixation and better utilization by plants. As nitrogen is an integral part of protein, higher availability and uptake of nitrogen under Rhizobium inoculation resulted in higher protein content in seed (Ola et al., 2014). The PSB like pseudomonas and bacillus also enhances the availability of phosphorus to the plant by converting inherent insoluble phosphorus into soluble form. The PSB like pseudomonas striata bacterial inoculation was found as equivalent to supply $50 \mathrm{~kg} \mathrm{P}_{2} \mathrm{O}_{5}$ per hectare through single superphosphate (Gour et al., 1980). Thus, microbial inoculation has been considered to be an integral part of integrated nutrient management system in major crops.

\section{Materials and Methods}

The present investigation was conducted during the rabi season in 2017-18 at Agronomy Instructional Farm of Chimanbhai Patel College of Agriculture, Sardarkrushinagar Dantiwada Agricultural University, Sardarkrushinagar, Dantiwada. It is situated in the North Gujarat Agro-climatic Zone. The soil of research farm was loamy sand in texture, poor in fertility and water holding capacity, having $\mathrm{pH} 7.61$, EC 0.11 $\mathrm{dS} / \mathrm{m}$; low in organic carbon $(0.31 \%)$ and available $\mathrm{N}(136.56 \mathrm{~kg} / \mathrm{ha})$ and medium in available $\mathrm{P}_{2} \mathrm{O}_{5}(43.41 \mathrm{~kg} / \mathrm{ha})$ and $\mathrm{K}_{2} \mathrm{O}(254.02$ $\mathrm{kg} / \mathrm{ha})$. The experiment consisting ten treatments comprised of $100 \%$ RDN through fertilizer $\left(\mathrm{T}_{1}\right), 100 \%$ RDN through FYM + Azotobacter + PSB $\left(\mathrm{T}_{2}\right), 100 \% \mathrm{RDN}$ through vermicompost + Azotobacter $+\mathrm{PSB}\left(\mathrm{T}_{3}\right), 100$ $\%$ RDN through castorcake + Azotobacter + PSB $\left(\mathrm{T}_{4}\right), 75 \%$ RDN through FYM $+25 \%$ RDN through fertilizer + Azotobacter + PSB $\left(\mathrm{T}_{5}\right), 75 \%$ RDN through vermicompost +25 $\%$ RDN through fertilizer + Azotobacter + PSB $\left(\mathrm{T}_{6}\right), 75 \%$ RDN through castorcake +25 $\%$ RDN through fertilizer + Azotobacter + PSB $\left(\mathrm{T}_{7}\right), 50 \%$ RDN through FYM $+50 \%$ RDN through fertilizer + Azotobacter + PSB $\left(\mathrm{T}_{8}\right), 50 \%$ RDN through vermicompost +50 $\%$ RDN through fertilizer + Azotobacter + PSB $\left(\mathrm{T}_{9}\right)$ and $50 \%$ RDN through castorcake $+50 \%$ RDN through fertilizer + Azotobacter $+\operatorname{PSB}\left(\mathrm{T}_{10}\right)$ were laid out in randomised block design with four replications. Seeds of cumin variety GC 4 was developed by Main Seed Spices Research Station, Jagudan. Biofertilizers namely Azotobacter and PSB consortium were procured from Department of Microbiology, Anand Agricultural University, Anand. For seed treatment $10 \mathrm{~g}$ jaggery was boiled in $100 \mathrm{ml}$ of water for half an hour and then cooled. In cooled jaggery solution $25 \mathrm{ml}$ biofertilizer of each culture was poured separately and stirred well. The seeds of cumin variety GC 4 was mixed thoroughly with the solution of culture and were allowed to dry in shade. The seeds were sown on the same day in bed size of $5.0 \times 3.6$ $\mathrm{m}^{2}$. Seeds were sown at $30 \mathrm{~cm}$ line spacing by broadcasting. The crop was fertilized as per treatments. The required quantity of FYM, vermicompost, castor cake were worked out and applied at 15 days before sowing of cumin crop. The full dose of phosphorus and $1 / 3^{\text {rd }}$ dose of nitrogen was applied as basal in the previously opened furrow to all the plots in form of SSP and Urea, respectively. The remaining $2 / 3$ rd dose of nitrogen was applied in two equal split in the form of urea at 10 and 30 DAS. Weeds are controlled by manual hand weeding as per need of the crop. 
Harvesting of the crop was done manually by pulling the dry plants out of the soil and threshing.

\section{Results and Discussion}

\section{Effect on growth attributes}

The result showed that the plant population per meter row length at 30 DAS and at harvest were not significantly influenced due to different treatments. It indicates that different treatments did not affect the germination as well as the survival of cumin plants (Table 1).

The data indicated that the plant height at 30 DAS was not significantly influenced due to different treatments. The plant height of cumin at harvest was significantly influenced by different treatments. Significantly higher plant height $(28.61 \mathrm{~cm})$ was recorded with the application of $50 \%$ RDN through vermicompost $+50 \%$ RDN through fertilizer + Azotobacter + PSB $\left(\mathrm{T}_{9}\right)$ and it remained at par with $50 \%$ RDN through castorcake +50 $\%$ RDN through fertilizer + Azotobacter + PSB $\left(\mathrm{T}_{10}\right), 50 \%$ RDN through FYM $+50 \%$ RDN through fertilizer + Azotobacter + PSB $\left(\mathrm{T}_{8}\right)$ and $100 \%$ RDN through fertilizer $\left(\mathrm{T}_{1}\right)$ with a plant height of 27.20, 26.11 and 25.88 $\mathrm{cm}$, respectively. This might be due to beneficial effect of vermicompost in improving the soil environment which in turn encourages proliferous root growth resulting in better absorption of moisture, nutrients and thus producing higher biomass. The results are closely associated with those reported by Munnu singh (2011) in coriander, Hnamte et al., (2013) in coriander and Shivran et al., (2014) in blond psyllium.

Significantly maximum number of branches per plant (7.75) was recorded with the application of $50 \%$ RDN through vermicompost $+50 \%$ RDN through fertilizer
+ Azotobacter + PSB $\left(\mathrm{T}_{9}\right)$ and it remained at par with $50 \%$ RDN through castorcake +50 $\%$ RDN through fertilizer + Azotobacter + PSB $\left(\mathrm{T}_{10}\right), 50 \%$ RDN through FYM $+50 \%$ RDN through fertilizer + Azotobacter + PSB $\left(\mathrm{T}_{8}\right)$ and $100 \%$ RDN through fertilizer $\left(\mathrm{T}_{1}\right)$ with a number of branches of 7.35, 7.10 and 6.95 , respectively. The better growth in terms of number of branches per plant might be due to added advantages of vermicompost, besides supplying all the essential nutrients. It is established fact that organic manures improves the physical and biological properties of soil including supply of almost all the essential plant nutrients for growth and development of plants. Thus, balance nutrition under favourable environment might have helped in production of new tissue and development of new shoots which ultimately increased the plant height, dry matter accumulation and number of branches per plant. These results are in close vicinity with the findings of Shivran et al., (2014) in blond psyllium, Hnamte et al., (2013) in coriander and Choudhary et al., (2006) in cumin.

\section{Effect on yield attributes and yield}

Significantly maximum number of umbels per plant (29.15) was recorded by the application of $50 \%$ RDN through vermicompost $+50 \%$ RDN through fertilizer + Azotobacter + PSB $\left(\mathrm{T}_{9}\right)$ and it remained at par with $50 \% \mathrm{RDN}$ through castorcake $+50 \%$ RDN through fertilizer + Azotobacter + PSB $\left(\mathrm{T}_{10}\right), 50 \%$ RDN through FYM + $50 \%$ RDN through fertilizer + Azotobacter + PSB $\left(\mathrm{T}_{8}\right)$ and $100 \%$ RDN through fertilizer $\left(\mathrm{T}_{1}\right)$ with a number of umbels per plant of 27.70, 27.55 and 27.00, respectively. Although, all yield attributes are decided by genetic makeup of that particular crop and variety, but the agronomic manipulation also affect them to a great extent. The reproductive growth depends on vegetative growth which increase leaf area and supply photosynthates for the formation 
of branches and other yield attributes. Therefore, biophysiochemical properties of soil plant system will influence buildup of yield attributes and the seed yield. For performing necessary physiological function to buildup different yield attributes these nutrients, inorganic and organic which have been integrated were possibly responsible for synthesizing necessary enzymes, proteins, energy (ATP and NADP), chlorophyll and other for the translocation of photosynthates and perhaps only because of these factors application of vermicompost alongwith inorganic and biofertilizers increased the number of yield attributes and seed yield. Similar observations have been reported by Dubey et al., (2012) in fenugreek, Singh et al., (2018) in dill and Gamar et al., (2018) in fennel (Table 2).

Significantly more number of umbellates per umbel (4.90) was recorded with the application of $50 \%$ RDN through vermicompost $+50 \%$ RDN through fertilizer + Azotobacter + PSB $\left(\mathrm{T}_{9}\right)$ and it remained at par with $50 \%$ RDN through castorcake +50 $\%$ RDN through fertilizer + Azotobacter + PSB $\left(\mathrm{T}_{10}\right), 50 \%$ RDN through FYM $+50 \%$ RDN through fertilizer + Azotobacter + PSB $\left(\mathrm{T}_{8}\right)$ and $100 \% \mathrm{RDN}$ through fertilizer $\left(\mathrm{T}_{1}\right)$ with a number of umbellates per umbel of $4.50,4.35$ and 4.35, respectively. Vermicompost might have increased the efficiency of added chemical fertilizer in soil, activities of $\mathrm{N}$ fixing bacteria and increased rate of humification. Humic acid in vermicompost might have enhanced the availability of both native and added nutrients in soil and as a result improved growth and yield attributes and yield of the crop significantly. Positive response of nitrogen and phosphorus increased availability of phosphorus in soil, being a major structural element of cell and helped in cell elongation, greater availability of photosynthates, metabolites and nutrients to develop reproductive structures which ascribed to increased growth parameters and lead to higher yield attributes and yields of cumin crop. These findings are in agreement with those of Gamar et al., (2018) in fennel and Singh et al., (2018) in dill.

Significantly higher number of seeds per umbellate (5.55) was recorded by the application of $50 \%$ RDN through vermicompost $+50 \%$ RDN through fertilizer + Azotobacter + PSB $\left(\mathrm{T}_{9}\right)$ and it remained at par with $50 \%$ RDN through castorcake +50 $\%$ RDN through fertilizer + Azotobacter + PSB $\left(\mathrm{T}_{10}\right), 50 \%$ RDN through FYM $+50 \%$ RDN through fertilizer + Azotobacter + PSB $\left(\mathrm{T}_{8}\right)$ and $100 \%$ RDN through fertilizer $\left(\mathrm{T}_{1}\right)$ with a number of seeds per umbellate of 5.15, 5.05 and 4.95, respectively. The positive response to combine application of organic manures and inorganic might be attributed to the better nutrient availability and its favorable effect on soil physical and biological properties resulting in increased yield attributes. The results supported by the findings of Shivran et al., (2014) in blond psyllium, Ashok et al., (2017) in fennel and Choudhary and Shivran (2009) in isabgol.

The data indicated that the test weight was not significantly influenced due to different treatments. However, numerically higher test weight $(3.74 \mathrm{~g})$ obtained with $\mathrm{T}_{9}(50 \% \mathrm{RDN}$ through vermicompost $+50 \%$ RDN through fertilizer + Azotobacter + PSB). while, lower test weight $(3.57 \mathrm{~g})$ observed with $\mathrm{T}_{2}(100 \%$ RDN through FYM + Azotobacter + PSB). The results are closely associated with those reported by Adhav et al., (2010) in fennel, Choudhary and Shivran (2009) in isabgol, Shivran et al., (2014) in isabgol and Singh et al., (2018) in dill.

Significantly higher seed yield (553 kg/ha) was recorded by the application of $50 \% \mathrm{RDN}$ through vermicompost $+50 \%$ RDN through 
fertilizer + Azotobacter + PSB $\left(\mathrm{T}_{9}\right)$ and it remained at par with $50 \%$ RDN through castorcake $+50 \%$ RDN through fertilizer + Azotobacter $+\mathrm{PSB}\left(\mathrm{T}_{10}\right), 50 \%$ RDN through $\mathrm{FYM}+50 \%$ RDN through fertilizer + Azotobacter + PSB $\left(\mathrm{T}_{8}\right)$ and $100 \% \mathrm{RDN}$ through fertilizer $\left(\mathrm{T}_{1}\right)$ with a seed yield of 525,515 and $500 \mathrm{~kg} / \mathrm{ha}$, respectively. This might due to effect of inorganic nutrients, organic nutrients and their combination on yield. Yield increased linearly with the number of umbel per plant, umbellate per umbel, seeds per umbel, 1000 seed weight, seed yield per plant, seed yield, straw yield, biological yield and harvest index. The results supported by the findings of Ashok et al., (2017) in fennel and Choudhary and Shivran (2009) in isabgol.

Table.1 Effect of integrated nutrient management on growth attributes of cumin

\begin{tabular}{|c|c|c|c|c|c|}
\hline \multirow[t]{2}{*}{ Treatments } & \multicolumn{2}{|c|}{$\begin{array}{c}\text { Plant population } \\
\text { (per meter row length) }\end{array}$} & \multicolumn{2}{|c|}{ Plant height (cm) } & \multirow{2}{*}{$\begin{array}{c}\text { Number of } \\
\text { branches per } \\
\text { plant }\end{array}$} \\
\hline & 30 DAS & At harvest & 30 DAS & At harvest & \\
\hline $\mathbf{T}_{1}$ & 14.00 & 11.75 & 4.74 & 25.88 & 6.95 \\
\hline $\mathbf{T}_{2}$ & 12.75 & 11.00 & 4.24 & 20.75 & 5.35 \\
\hline $\mathbf{T}_{3}$ & 13.00 & 11.25 & 4.38 & 21.45 & 6.10 \\
\hline $\mathbf{T}_{4}$ & 13.00 & 11.25 & 4.31 & 21.04 & 5.95 \\
\hline $\mathbf{T}_{5}$ & 13.50 & 11.50 & 4.62 & 23.68 & 6.15 \\
\hline$T_{6}$ & 13.75 & 11.75 & 4.72 & 24.79 & 6.75 \\
\hline $\mathbf{T}_{7}$ & 13.75 & 11.75 & 4.67 & 24.24 & 6.45 \\
\hline $\mathbf{T}_{8}$ & 14.00 & 12.00 & 4.81 & 26.11 & 7.10 \\
\hline $\mathbf{T}_{9}$ & 14.50 & 12.50 & 4.86 & 28.61 & 7.75 \\
\hline $\mathbf{T}_{10}$ & 14.25 & 12.25 & 4.83 & 27.20 & 7.35 \\
\hline S.Em. \pm & 0.40 & 0.36 & 0.16 & 1.28 & 0.30 \\
\hline C. D. $(P=0.05)$ & NS & NS & NS & 3.70 & 0.87 \\
\hline C. V. $\%$ & 5.86 & 6.13 & 7.01 & 10.48 & 9.12 \\
\hline
\end{tabular}

Table.2 Effect of integrated nutrient management on yield attributes and yield of cumin

\begin{tabular}{|c|c|c|c|c|c|c|c|}
\hline Treatments & $\begin{array}{c}\text { Number of } \\
\text { umbels per } \\
\text { plant }\end{array}$ & $\begin{array}{c}\text { Number of } \\
\text { umbellates } \\
\text { per umbel }\end{array}$ & $\begin{array}{c}\text { Number of } \\
\text { seeds per } \\
\text { umbellate }\end{array}$ & $\begin{array}{c}\text { Test } \\
\text { weight } \\
\text { (g) }\end{array}$ & $\begin{array}{c}\text { Seed } \\
\text { yield } \\
\text { (kg/ha) }\end{array}$ & $\begin{array}{c}\text { Straw } \\
\text { yield } \\
\text { (kg/ha) }\end{array}$ & $\begin{array}{c}\text { Harvest } \\
\text { index } \\
(\mathbf{\%})\end{array}$ \\
\hline $\mathbf{T}_{\mathbf{1}}$ & 27.00 & 4.35 & 4.95 & 3.70 & 500 & 774 & 39.24 \\
\hline $\mathbf{T}_{\mathbf{2}}$ & 24.00 & 2.50 & 3.50 & 3.57 & 400 & 640 & 38.37 \\
\hline $\mathbf{T}_{\mathbf{3}}$ & 25.00 & 3.05 & 4.20 & 3.63 & 429 & 671 & 38.86 \\
\hline $\mathbf{T}_{\mathbf{4}}$ & 24.25 & 2.85 & 3.85 & 3.60 & 421 & 655 & 39.06 \\
\hline $\mathbf{T}_{\mathbf{5}}$ & 25.50 & 3.30 & 4.25 & 3.64 & 462 & 717 & 39.07 \\
\hline $\mathbf{T}_{\mathbf{6}}$ & 25.75 & 3.85 & 4.70 & 3.67 & 479 & 747 & 39.08 \\
\hline $\mathbf{T}_{\mathbf{7}}$ & 25.55 & 3.55 & 4.55 & 3.65 & 465 & 722 & 39.04 \\
\hline $\mathbf{T}_{\mathbf{8}}$ & 27.55 & 4.35 & 5.05 & 3.70 & 515 & 793 & 39.26 \\
\hline $\mathbf{T}_{\mathbf{9}}$ & 29.15 & 4.90 & 5.55 & 3.74 & 553 & 867 & 38.94 \\
\hline $\mathbf{T}_{\mathbf{1 0}}$ & 27.70 & 4.50 & 5.15 & 3.71 & 525 & 820 & 39.10 \\
\hline S.Em. $\mathbf{m}$ & 1.07 & 0.21 & 0.22 & 0.04 & 24 & 34 & 0.55 \\
\hline C. D. (P=0.05) & 3.12 & 0.60 & 0.65 & NS & 71 & 98 & NS \\
\hline C. V. $\mathbf{~}$ & 8.22 & 11.08 & 9.82 & 2.12 & 10.30 & 9.14 & 2.83 \\
\hline
\end{tabular}


Table.3 Effect of integrated nutrient management on economics of cumin

\begin{tabular}{|c|c|c|c|c|c|c|}
\hline Treatments & $\begin{array}{c}\text { Seed } \\
\text { yield } \\
\text { (kg/ha) }\end{array}$ & $\begin{array}{c}\text { Straw } \\
\text { yield } \\
\text { (kg/ha) }\end{array}$ & $\begin{array}{c}\text { Gross } \\
\text { income } \\
\text { (₹ /ha) }\end{array}$ & $\begin{array}{c}\text { Cost of } \\
\text { cultivation } \\
\text { (₹ /ha) }\end{array}$ & $\begin{array}{c}\text { Net income } \\
\text { (₹ /ha) }\end{array}$ & $\begin{array}{c}\text { Benefit } \\
\text { cost } \\
\text { ratio }\end{array}$ \\
\hline T1 & 500 & 774 & 75774 & 28083 & 47691 & 2.70 \\
\hline T2 & 400 & 640 & 60640 & 32388 & 28252 & 1.87 \\
\hline T3 & 429 & 671 & 65021 & 40918 & 24103 & 1.59 \\
\hline T4 & 421 & 655 & 63805 & 35588 & 28217 & 1.79 \\
\hline T5 & 462 & 717 & 70017 & 31327 & 38690 & 2.24 \\
\hline T6 & 479 & 747 & 72597 & 37724 & 34873 & 1.92 \\
\hline T7 & 465 & 722 & 70472 & 33727 & 36745 & 2.09 \\
\hline T8 & 515 & 793 & 78043 & 30266 & 47778 & 2.58 \\
\hline T9 & 553 & 867 & 83817 & 34531 & 49287 & 2.43 \\
\hline T10 & 525 & 820 & 79570 & 31866 & 47705 & 2.50 \\
\hline
\end{tabular}

Selling price of cumin (₹/kg): (i) Seed: 150 (ii) Straw: 1

Significantly higher straw yield $(867 \mathrm{~kg} / \mathrm{ha})$ was recorded under the application of $50 \%$ RDN through vermicompost $+50 \%$ RDN through fertilizer + Azotobacter + PSB $\left(\mathrm{T}_{9}\right)$ and it remained at par with $50 \%$ RDN through castorcake $+50 \%$ RDN through fertilizer + Azotobacter + PSB $\left(\mathrm{T}_{10}\right), 50 \%$ RDN through FYM $+50 \%$ RDN through fertilizer + Azotobacter $+\mathrm{PSB}\left(\mathrm{T}_{8}\right)$ and $100 \%$ RDN through fertilizer $\left(T_{1}\right)$ with a straw yield of 820,793 and $774 \mathrm{~kg} / \mathrm{ha}$, respectively. The significant increase in seed yield under the influence of vermicompost was largely a function of improved growth and development of the plants. The positive response to combine application of organic manures and inorganic fertilizers might be attributed to the better nutrient availability and its favorable effect on soil physical and biological properties resulting in increased yield. The increased yield might also be due to better nutritional status of the soil which might have stimulated the rate of various plant physiological processes and led to increased growth and yield attributing characteristics and their cumulative effect resulted in enhanced seed and straw yields of cumin. The results supported by the findings of Shivran et al., (2014) in blond psyllium.
The data showed that harvest index was not significantly influenced due to different treatments.

\section{Effect on economics}

A perusal of data on gross return as influenced due to different treatments indicated that the higher gross realization of ₹ 83817/ha was obtained with treatment 50 $\%$ RDN through vermicompost $+50 \%$ RDN through fertilizer + Azotobacter $+\mathrm{PSB}\left(\mathrm{T}_{9}\right)$ followed by treatment $50 \%$ RDN through castorcake $+50 \%$ RDN through fertilizer + Azotobacter + PSB $\left(\mathrm{T}_{10}\right)$ and $50 \%$ RDN through FYM + $50 \%$ RDN through fertilizer + Azotobacter + PSB $\left(\mathrm{T}_{8}\right)$. The lowest (₹ 60640/ha) gross realization was noticed under treatment $100 \%$ RDN through FYM + Azotobacter + PSB $\left(\mathrm{T}_{2}\right)$. The results confirm the findings of Shivran et al., (2015) in fennel (Table 3).

A perusal of data on net realization revealed that higher net realization of ₹ 49287/ha was recorded with treatment $50 \%$ RDN through vermicompost $+50 \% \mathrm{RDN}$ through fertilizer + Azotobacter + PSB $\left(\mathrm{T}_{9}\right)$ followed by treatment $50 \%$ RDN through FYM $+50 \%$ 
RDN through fertilizer + Azotobacter + PSB $\left(\mathrm{T}_{8}\right), 50 \%$ RDN through castorcake $+50 \%$ RDN through fertilizer + Azotobacter + PSB $\left(\mathrm{T}_{10}\right)$ and $100 \%$ RDN through fertilizer $\left(\mathrm{T}_{1}\right)$. The lowest net realization ( $₹ 24103 /$ ha) was noticed under treatment $100 \%$ RDN through vermicompost + Azotobacter $+\operatorname{PSB}\left(\mathrm{T}_{3}\right)$. These findings are in agreement with those of Choudhary et al., (2006) in cumin, Jain et al., (2007) in fennel, Kalidasu et al., (2008) in coriander, Singh (2014) in coriander and Jhankar et al., (2017) in coriander.

Examination of data on BCR indicated that higher BCR of 2.70 was observed with treatment $100 \%$ RDN through fertilizer $\left(\mathrm{T}_{1}\right)$ followed by treatment $50 \%$ RDN through FYM + $50 \%$ RDN through fertilizer + Azotobacter + PSB $\left(\mathrm{T}_{8}\right), 50 \% \mathrm{RDN}$ through castorcake $+50 \%$ RDN through fertilizer + Azotobacter + PSB $\left(\mathrm{T}_{10}\right)$ and $50 \%$ RDN through vermicompost $+50 \%$ RDN through fertilizer + Azotobacter $+\mathrm{PSB}\left(\mathrm{T}_{9}\right)$. The lowest BCR of 1.59 was noted with treatment $100 \%$ RDN through vermicompost + Azotobacter + PSB $\left(\mathrm{T}_{3}\right)$. The results supported by the findings of Patel et al., (2003) in fennel, Adhav et al., (2010) in fennel, Godara et al., (2014) in coriander and Godara et al., (2014) in fennel.

\section{References}

Adhav, S. L.; Shete, P. G. and Kushare, Y. M., 2010. Influence of organic and inorganic sources of nitrogen on growth and yield of rabi drilled fennel (Foeniculum vulgare Mill.). International Journal of Agricultural Sciences. 6 (1): 58-60.

Ashok, K. B.; Naruka, I. S.; Rathore, G. P. S.; Sktawat, R. P. S.; Rajveer; Saniya and Sowmya, P. T., 2017. Effect of integrated nutrient management on growth, yield and quality of fennel (Foeniculum vulgare Mill.).
International Journal of Chemical Studies. 5 (5): 397-399.

Choudhary, G. R.; Jain, N. K. and Jat, N. L., 2006. Response of cumin (Cuminum cyminum L.) to inorganic nitrogen, farmyard manure and biofertilizer. Indian Journal of Agronomy. 51 (4): 334-336.

Choudhary, I. and Shivran, A. C., 2009. Effect of integrated nutrient management on yield, quality and nutrient uptake of isabgol. Annual Agriculture Research New Series. 30 (3\&4): 105-107.

Dubey, P. K.; Pandey, C. S.; Khanday, A. S. and Mishra, G., 2012. Effect of integrated nutrient management on nutrient uptake, protein content and yield of fenugreek. International Journal of Food, Agriculture and Veterinary Sciences. 2 (1): 1-12.

Gamar, P.; Mevada, K. D.; Ombase, K. C.; Bhadane, R. S. and Patel, P. D., 2018. Influence of integrated nutrient management on yield, quality and nutrient status of drilled rabi fennel (Foeniculum vulgare Mill.). Journal of Pure and Applied Microbiology. 11 (3): 1559-1565.

Godara, A. S.; Gupta, U. S.; Lal, G. and Singh, R., 2014 ${ }^{\mathrm{a}}$. Influence of organic and inorganic sources of fertilizers on growth, yield and economics of fennel (Foeniculum vulgare Mill.) cultivation under semi arid conditions. Journal of Spices and Aromatic Crop. 23 (2): 200204.

Godara, A. S.; Gupta, U. S.; Lal, G. and Singh, R., 2014 ${ }^{\mathrm{b}}$. Influence of organic and inorganic source of fertilizers on growth, yield and economics of coriander (Coriandrum sativum L.). International Journal of Seed Spices. 4 (2): 77-80.

Gour, A. C.; Oswal, K. P. and Mathur, R. S., 1980. Save super phosphate by using 
phosphate solubilizing culture and rock phosphate, Kheti. 32 (10): 23-25.

Hnamte, V.; Chatterjee, R. and Tania, C., 2013. Growth, flowering, fruit setting and maturity behaviour of coriander (Coriandrum sativum L.) with organics including biofertilizers and inorganic. The Bioscan. 8 (3): 791-793.

Jain, N. K.; Jat, N. L. and Chaudhary, G. R., 2007. Response of fennel (Foeniculum vulgare Mill.) to inorganic nitrogen, farmyard manure and Azospirillum. Indian Journal of Agricultural Sciences. 77 (6): 376-378.

Jhankar, P.; Panda, C. M. and Sethi, D., 2017. Effect of INM practices on yield, yield attributes and economics of coriander (Coriandrum sativum L.). International Journal of Current Microbiology and Applied Sciences. 6 (5): 1306-1312.

Kalidasu, G.; Sarada, C. and Reddy, T. Y., 2008. Efficacy of biofertilizers on the performance of rainfed coriander (Coriandrum sativum L.) in vertisols. Journal of Spices and Aromatic Crops. 17 (2): 98-102.

Munnu Singh, 2011. Effect of vermicompost and chemical fertilizers on growth, yield and quality of coriander (Coriandrum sativum L.) in semi-arid tropical climate. Journal of spices and Aromatic crops. 20 (1): 30-33.

Ola, B. L.; Pareek, B. L.; Kumawat, A.; Tiwari, D. K.; Jeetarwal, R. L. and Dhayal, M. L., 2014. Productivity, profitability and quality of groundnut as affected by integrated nutrient management. Annals of Agri-Bioresearch. 19 (4): 692-696.

Patel, B. S.; Amin, A. V.; Patel, K. P. and Patel, M. M., 2003. Influence of organic manure alone or in combination with inorganic fertilizer on producing of winter drilled fennel. Indian Journal of Agronomy. 48 (3): 232-234.

Shivran, A. C. and Jat, N. L., 2015. Integrated nutrient management influenced growth, yield and economics of fennel (Foeniculum vulgare Mill.) under semi arid conditions. Indian Journal of Agronomy. 60 (2): 318-323.

Shivran, A. C.; Choudhary, I. and Puniya, M. M., 2014. Influnce of integrated nutrient management and biofertilizer on growth, yield and soil fertility of blond psyllium cultivation under semi- arid condition. Annual Agriculture Research New Series. 35 (4): 379-385.

Singh, P.; Naruka, I. S.; Gallani, R. and Singh O. P., 2018. Effect of different INM practices on productivity of dill and on post-harvest soil properties in vertisol. International Journal of Current Microbiology Applied Science. 7 (Special): 3632-3637.

Singh, S. P., 2014. Effect of biofertilizer Azospirillum on growth and yield parameters of coriander (coriandrum sativum L.) cv. Pant haritima. International Journal of Seed Spices. 4 (2): 73-76.

\section{How to cite this article:}

Desai, S. S., M. G. Chaudhary, R. S. Patel and Joshi, J. R. 2020. Effect of Integrated Nutrient Management on Growth, Yield and Economics of Cumin (Cuminum cyminum L.). Int.J.Curr.Microbiol.App.Sci. 9(11): 3712-3719. doi: https://doi.org/10.20546/ijcmas.2020.911.445 